\title{
Assessing livelihood status of migrants from northern Ghana resident in the Obuasi Municipality
}

\author{
Augustine Tanle
}

Published online: 11 December 2013

(C) The Author(s) 2013. This article is published with open access at Springerlink.com

\begin{abstract}
In Ghana, studies on migration and livelihoods are mostly limited to migrants' places of origin. This paper therefore assesses livelihood status of permanent migrants resident in the Obuasi Municipality who hail from the northern parts of Ghana. The instrument used was a survey questionnaire and the respondents were both migrants and indigenes aged 18 years and above. The findings showed no significant differences between migrants and indigenes in ownership of assets and consumer durable goods and housing quality. However, the indigenes earned relatively higher than the migrants due to access to various forms of capital and the influence of institutional structures and processes. But to the migrants, their livelihood status has improved since they have built houses, educated their children, remitted relations at home and have acquired some consumer durable goods. Improvement in the livelihood status of migrants could induce further north-south migration. There is therefore the need for government and other stakeholders to bridge the gap of unequal socioeconomic development between the northern and southern parts of the country.
\end{abstract}

Keywords North-south migration .

Livelihood status $\cdot$ Migrants $\cdot$ Obuasi · Ghana

\footnotetext{
A. Tanle $(\square)$

University of Cape Coast, Cape Coast, Ghana

e-mail: augtanle@yahoo.com
}

\section{Introduction}

In the 1990s, the World Bank, multinational and bilateral aid agencies introduced the concept of sustainable livelihood as a new approach to poverty reduction following the adverse effects of the Structural Adjustment Programme (SAP) and Economic Recovery Programme (ERP) on the economies of adjusting countries (Camdessus 1990; Overseas Development Administration (ODA) 1995). In Ghana, the SAP, among other things, encouraged investment in the production of export commodities (cash crops and minerals) which are mostly found in the southern parts of the country to the neglect of the three northern regions, which are predominantly food crops and livestock production areas. Consequently, SAP intensified labour migration from the northern to the southern parts of the country which existed since the colonial era. The three northern regions (Northern, Upper East and Upper West Regions) have acted as a labour reservoir supplying labourers to the mines (Songsore 2003; Yaro 2006; Abane 2008). For instance, in the 1919 Development Plan launched by Guggisberg, it was estimated that 27, 000 men were needed and therefore a special recruitment scheme was organized in the Northern Territories. Chiefs and other opinion leaders were mandated by the then District Commissioners in the Northern Territories to recruit men as labourers to the mines and cocoa farms in the south (Songsore and Denkabe 1995; Anarfi et al. 2003; Yaro 2006). 
The policy of forced labour recruitment ended before political independence in 1957; but this was replaced by voluntary migration in response to the need for labour in mining areas such as Obuasi (Songsore and Denkabe 1995; Anarfi et al. 2003; Songsore 2003; Tsegai 2005).

In general, migration is considered as a key livelihood diversification strategy for both poor and non-poor households (Narayan et al. 2000; Kothari 2002; Alam and Streatfield 2009; Collinson et al. 2009; UNDP 2009). Studies on migration and livelihood status of migrants' households at the places of origin are widely documented in the literature (Kothari 2002; Heering et al. 2004; Geest 2005; Yaro 2006; Young 2006). For instance, in a study on migration and livelihoods, it was observed that migrants brought home with them material items and practical skills which improved household livelihood status (De Haan et al. 2000). Similarly, Young (2006) noted that labour migration and remittances were the second most important source of food and income, after agriculture, for poorer households.

In focus group discussions (FGDs) held with some permanent migrants from the Upper West Region resident in rural areas of both the Wenchi and Techiman Districts, Geest (2005) observed that through remittances, the migrants acquired some consumer durable goods, invested in housing and improved upon food security at their hometowns. Furthermore, a study on livelihood activities in rural northern Ghana indicates that remittances from migrants resident in the south to their relations in the north play important roles in paying school and hospital fees, investment and household infrastructure (Yaro 2006). In general, studies focusing on migration and livelihood at places of origin have shown that, through migration, return migrants have brought home some consumer durable goods and have also invested in both agriculture and non-agricultural enterprises which had improved the livelihood status of the migrants' households (Yaro 2006; Collinson et al. 2009; Pinnawala 2009).

However, there is paucity of literature on livelihood status of migrants at destination, particularly in Ghana (Tanle 2010). This has resulted in diverse perceptions about livelihood status of migrants at destination. In the three northern regions, for example, the general perception among non-migrants has been that their counterparts (migrants from the three regions) resident in the southern parts of the country enjoy better livelihood status (Geest 2005). This study employs the livelihood framework to assess the livelihood status of migrants from the three northern regions who are permanent residents in the Obuasi Municipality, one of the traditional destinations of migrants from the northern parts of Ghana (Nabila 1985; Anarfi et al. 1999; Geest 2005; Songsore 2003).

The main objective of this paper is to assess the livelihood status of these permanent migrants resident in the Obuasi Municipality. To ensure an objective assessment of the livelihood status of the migrants, their livelihood status was compared with that of the indigenes. Improvement or deterioration in the livelihood status of migrants at destination has policy implications for both the places of origin and destination. The study is underpinned by the hypothesis that there is no significant difference in livelihood status between migrants and indigenes in the Obuasi Municipality.

\section{Conceptual and theoretical issues}

Chamber and Conway (1992) define 'livelihood' as the capabilities, assets, and activities required for a means of living. It is based on the assumption that asset status is fundamental to understanding the options open to an individual, the strategies that can be adopted to attain a livelihood, the outcomes aspired to and the vulnerability context under which one operates (Ellis 2003). The livelihood concept is derived from the 'sustainable livelihood' approach which has been defined broadly as a means of living which is resilient to shocks and stresses, and also does not adversely affect the environment (Meikle et al. 2001).

The concept of sustainable livelihood (SL) first appeared in the report of an advisory panel of the World Commission on Environment and Development (WCED) titled Food 2000 (Cahn 2002). Since the Food 2000 report, concurrent discourses on poverty, sustainability and livelihood systems have led to the formalization and development of various livelihood approaches. This paper adopts the Sustainable Livelihood Framework for the Pacific Island by Cahn (2002) as its conceptual framework (Fig. 1). It has some comparative advantages over the others. It recognizes diverse livelihood strategies, whether 
natural resource based or non-natural resource based, which include migration which is the focus of this paper. Also, it provides a wide range of indicators such as monetary, non-monetary and food security for measuring livelihood outcomes and its last component, well being, measures the overall livelihood outcome, which could be positive or negative or neutral.

The Sustainable Livelihood Frameworks for the Pacific Island is a modification of the DFID framework. Unlike the DFID framework which has five components, it has six main components namely, livelihood access/capitals/resources, livelihood strategies, influencing structures and processes, vulnerability context, livelihood outcomes and well being.

Livelihood capital/resources have been categorized into six: natural, financial, human, social, traditional and physical (Cahn 2002). The natural capital/assets include land, water, trees and wildlife. In urban areas some people depend on land for small-scale intensive agriculture or animal husbandry or for housing purposes while others too eke out a living from common property resources such as rivers/streams and trees. Financial capital comprises money, loan access and savings. Income derived from the sale of labour is a key asset in urban setting which increases dependency on cash income as a result of the commoditized nature of urban areas (Moser 1998). The availability and accessibility of affordable credits is important in promoting livelihood activities in urban areas (Meikle et al. 2001).

Human capital covers skills, education and health. While the sale of labour is very crucial in the context of the urban economy, health care is also vital in determining the quality of labour with access to formal education and skills training providing the opportunity for people to improve upon the value of their human capital (Meikle et al. 2001). Social capital consists of networks and associations. Social networks facilitate access to information about economic opportunities and also serve as safety net that migrants could rely on during crises. Traditional capital comprises beliefs, norms, values, language and aspirations of individuals or social groups. These can influence migrants' perceptions, attitudes and behaviours in the type of livelihood strategies that they adopt as well as how they perceive their livelihood status.

Infrastructural facilities such as housing, education, health, roads and electricity are among the physical capital needed in urban areas to facilitate livelihood

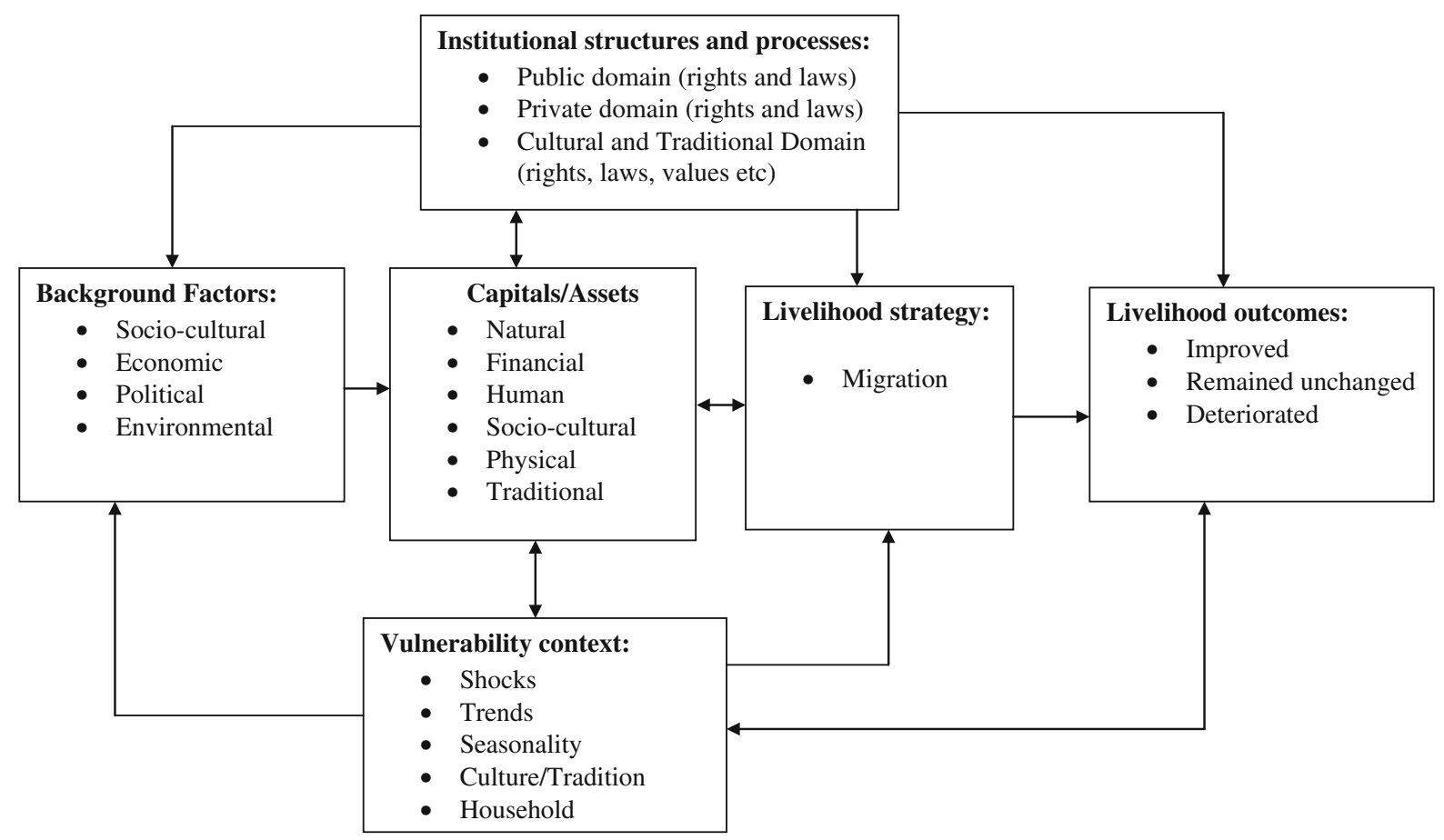

Fig. 1 A conceptual framework on migration and livelihoods. Source Adapted from Cahn (2002) 
activities. In particular, housing is often one of the most important assets or capitals that urban dwellers need for both productive and reproductive purposes (Moser 1998). Although various forms of assets exist at both the household and community levels, access to assets owned by a household or access to common community property may vary depending on the power relations at the household or community level (Farrington et al. 2002). In communities where migrants are excluded from accessing common community property or are allowed access but ought to pay large amounts of money or accept some unfavourable terms, migrants are not likely to improve upon their livelihood status as much as they would have wished.

The next component of the conceptual framework is livelihood strategies. In general, livelihood strategies have been identified as agricultural intensification or extensification, livelihood diversification including both paid employment and rural enterprises, and migration (including income generation and remittances) (Scoones 1998; Carney 1998; Ellis 2000, Cahn 2002). Generally, people tend to choose livelihood strategies which, in their estimation, provide them with the best or optimum livelihood outcomes. Migration is one of such strategies that people adopt in pursuit of a living. This, however, depends on a number of factors such as the assets/capitals that people have, the institutional structures and processes that impact on them, and the vulnerability context under which they operate.

The other component of the framework is institutional structures and processes. These serve as transforming factors and consist of public domain, private sector domain and traditional domain, which includes gender. They are basically internal or external laws, policies or regulations, norms, beliefs and incentives that could have positive or adverse effects on livelihood strategies, livelihood outcomes and wellbeing.

One other external component of the framework, which influences access to capital, livelihood strategies and livelihood outcomes, is the element of vulnerability. Citing from Moser (1998), Meikle et al. (2001) define vulnerability as the insecurity of the well-being of individuals or communities in the face of changing environments (ecological, social, economic and political) in the form of sudden shock, long term trends, or seasonal cycles. It provides the external environment within which people live and seek livelihoods. In an attempt to improve upon their livelihood status, migrants may pursue their livelihoods within the context of vulnerability. For migrants in urban areas, this could include job insecurity in both formal and informal sectors and personal shocks of chronic illnesses (Ellis 2003) and death of an adult member could make some or all the other members vulnerable and unable to improve upon their livelihood status.

The ultimate component of the framework is livelihood outcomes which broadly comprise monetary and non-monetary elements. The outcomes could be positive, negative or neutral. Migration is one of the livelihood strategies that people adopt in order to improve upon their livelihood status. Generally, north-south migration in Ghana can be situated within the context of the livelihood framework given the differences in the background characteristics between the northern and southern parts of the country. However, whether migrants succeed in improving their livelihood status depends on a number of factors which include the capitals/assets that they may possess, institutional structures and processes that influence the livelihood activity that they engage in and the vulnerability context within which they operate.

\section{Study area}

The Obuasi Municipal Assembly, formerly known as Adansi West District Assembly, came into being through Executive Instrument No. (E.I. 15) of 15th December 2003 and Legislative Instrument (L. I. 1795) of 17th March, 2007 (Tanle 2010) (Fig. 2). The Municipality is located between latitude 5.35 and $5.65 \mathrm{~N}$ and longitude 6.35 and $6.90 \mathrm{~N}$. It covers a land area of $162.4 \mathrm{sqkm}$ (www.ghanadistricts.com). It experiences semi-equatorial climatic conditions with a double maximum rainfall regime. Mean annual rainfall ranges between 125 and $175 \mathrm{~cm}$. Temperatures are uniformly high all year round with the hottest month being March when $30{ }^{\circ} \mathrm{C}$ is usually recorded (Tanle 2010). The underlying rocks are mainly of the birrimain formation which contains most of the minerals (particularly Gold) exported from the country (Dickson and Benneh 1988). The soils which are the forest ochrosols type are generally fertile.

The total population of Obuasi Municipality was estimated at 168,641 in 2010 , rising from 60,617 in 
Fig. 2 Map of the Obuasi Municipality showing the study areas. Source GIS Unit of Department of Geography and Regional Planning, University of Cape Coast

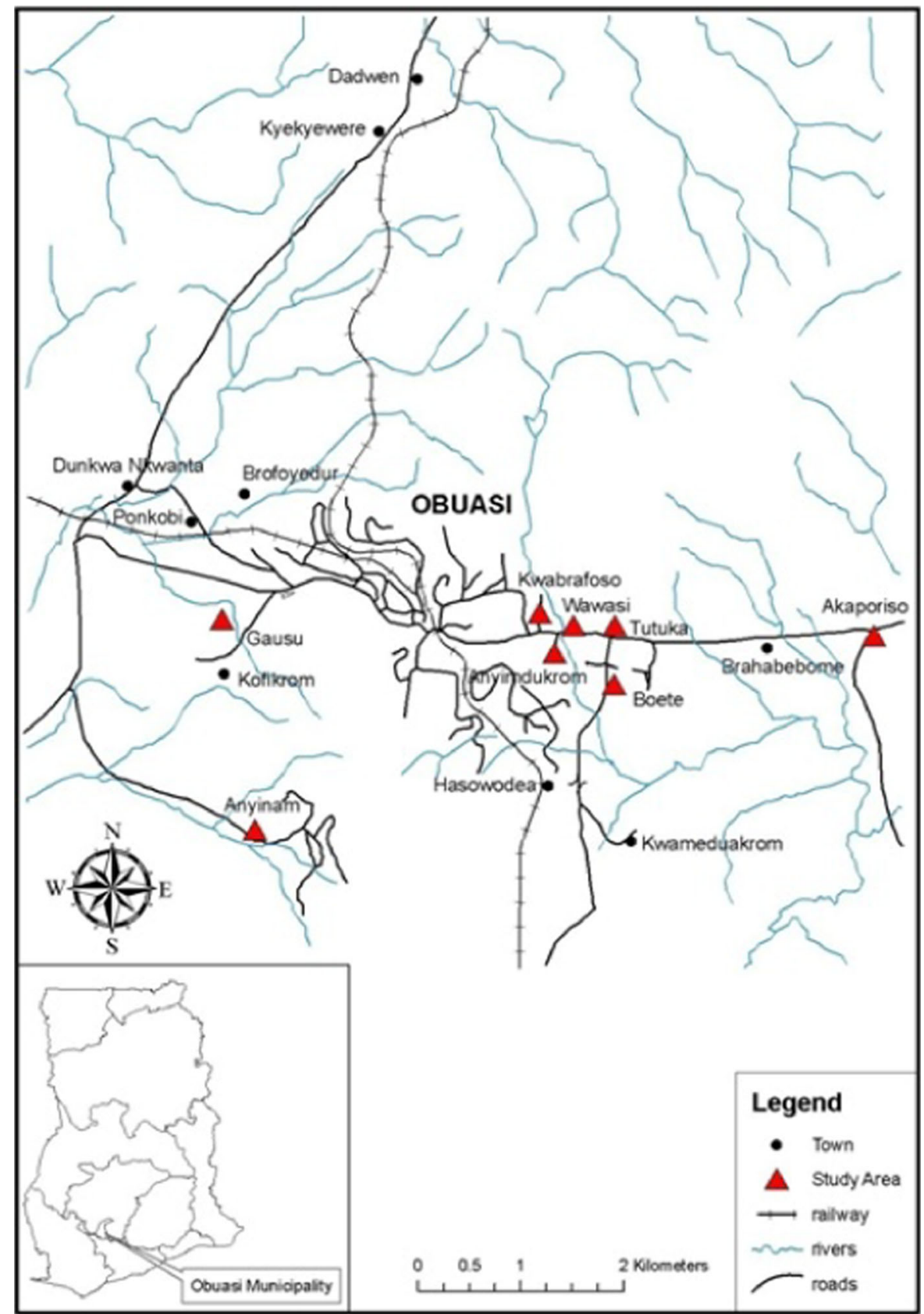

1984 to 115,564 in 2000 . It had a population density of 1,201 persons per sq $\mathrm{km}$. A number of roads traverse the Municipality and also link the Municipality to other parts of the country. Educational institutions in the Municipality include 59 Basic Schools, three Senior Secondary Schools and four Vocational Institutions. The Municipality has 19 hospitals and clinics which provide healthcare services to the people. Banking institutions in the Municipality include five
Commercial Banks, four Rural Banks and Microfinance institutions.

Owing to its geological formation, the main economic activity in the Obuasi Municipality is gold mining which has made Obuasi one of the popular destinations for migrants from the three northern regions. Also, the physical characteristics (natural capital) of the area promote food and cash crops farming while commercial activities include leather 
works and petty trading. There are three main daily markets and eight satellite markets within the Municipality. All these diverse livelihood resources attract people including migrants from the three northern regions to the Municipality where they engage in various livelihood activities in order to improve upon their livelihood status.

\section{Data and methods}

The data for the study were drawn from a much wider study (Tanle 2010). The respondents were first generation permanent migrants from the three northern regions resident in the Obuasi Municipality and the indigenes of Obuasi. A migrant in the study refers to a first generation migrant born in any part of the three northern regions who owes allegiance to that place but has been a permanent resident in the Obuasi Municipality for at least 5 years preceding the time of the survey (some national surveys have used 5 years as a benchmark for assessing changes in socio-economic status) (Ghana Statistical Service 2002). One main weakness of the methodology is that though the migrants are permanent residents like the indigenes, they came to the Obuasi Municipality at different ages and time periods but data was not collected on these variables.

In the study, an indigene was defined as a person born in the Obuasi Municipality through parentage of generations and who has lived all his/her life there, except for temporary visits or vacations elsewhere for a period of less than a year (Ghana Statistical Service 2000). The indigenes included in the study served as a control group against which livelihood status of migrants was compared.

Through a preliminary survey, eight communities in the Obuasi Municipality mostly resided by migrants from the northern parts of the country and some indigenes were purposively selected. The communities selected were Akaporiso, Anyinam, Gausu, Wawasi, Kwabrafoso, Tutuka, Anyimadukrom and Boete (see Fig. 2). The total number of migrants and indigenes was not known and therefore a sample size could not be determined. However, using the snowball and systematic sampling techniques (also based on the resources available for the study), 151 migrants and 148 indigenes were interviewed. First, the two categories of respondents were identified through the snowball sampling technique and then a list of household heads was prepared in each case. From the list, household heads were systematically selected. A household was defined as a residential group of persons who live under the same roof and eat out of the same pot (Friedman 1992).

A survey questionnaire, an in-depth interview (IDIs) and a focus group discussion (FGDs) guides were the main instruments used. The questionnaire included questions on background characteristics of respondents, main occupation prior to and after migration, perceptions of financial situation before and after migration, ownership of assets and consumer durable goods, quality of housing and assessment of livelihood status. The interview and discussion guides had similar themes like the questionnaire, and were employed to complement information from the questionnaire because livelihood status can best be described by respondents themselves.

Four FGDs comprising male and female groups (i.e. two each for migrants and indigenes) were conducted among the migrants and indigenes who were aged between 30 and 60 years and were mostly miners, teachers, farmers, housewives and traders. Also, a total of 20 IDIs were conducted among chiefs/ elders/opinion leaders from the migrants and indigenes.

\section{Results}

Background characteristics by migration status

Background characteristics of a respondent could influence the type of livelihood activity that one engages in, and consequently one's livelihood status. The respondents in both cases were mostly males (Table 1). This was expected since heads of households in Ghana are mostly males (Ghana Statistical Service 2002). Generally, the migrants were younger than the indigenes as indicated by their respective modal ages. Almost the same proportion of migrants and indigenes were married, and in both cases they were mostly Christians. Seven out of ten indigenes compared with three out of ten migrants have had higher education (Secondary school education or beyond) while a third of the migrants and about one per cent of the indigenes have had no formal education. Nearly half of the migrants and about two-thirds of the indigenes lived in 
households with 4-6 members and this figure is above the national average household size of 4.4 (Ghana Statistical Service 2012).

Main occupation by education and migration status

As an aspect of human capital, education is a critical factor that influences livelihood outcomes (Waddington and Sabates-Wheeler 2003). Table 2 shows that migrants were mostly engaged in mining compared to the indigenes, particularly those with Middle/JHS education (75.0 per cent). Two-thirds of the indigenes with higher education were in the civil service compared with about two out of ten of the migrants.

Table 1 Background characteristics by migration status

\begin{tabular}{|c|c|c|}
\hline \multirow{2}{*}{$\begin{array}{l}\text { Background characteristic } \\
\text { Sex }\end{array}$} & \multicolumn{2}{|c|}{ Migration status } \\
\hline & Indigenes & Migrants \\
\hline Male & 84.5 & 92.7 \\
\hline Female & 15.5 & 7.3 \\
\hline \multicolumn{3}{|l|}{ Age } \\
\hline$<35$ & 8.1 & 17.2 \\
\hline $35-44$ & 20.9 & 31.1 \\
\hline $45-54$ & 33.1 & 30.5 \\
\hline $55+$ & 37.8 & 21.2 \\
\hline \multicolumn{3}{|l|}{ Marital status } \\
\hline Single & 4.7 & 6.0 \\
\hline Married & 79.1 & 80.1 \\
\hline Ever married & 16.2 & 13.9 \\
\hline \multicolumn{3}{|l|}{ Highest educational level } \\
\hline None & 0.7 & 31.8 \\
\hline Primary & 1.4 & 17.2 \\
\hline Middle/JHS & 27.0 & 15.9 \\
\hline Higher & 70.9 & 35.1 \\
\hline \multicolumn{3}{|l|}{ Religious affiliation } \\
\hline Christianity & 89.2 & 55.6 \\
\hline Islam & 2.0 & 39.1 \\
\hline Traditional & 8.8 & 5.3 \\
\hline \multicolumn{3}{|l|}{ Household size } \\
\hline $1-3$ & 17.6 & 19.9 \\
\hline $4-6$ & 64.9 & 47.0 \\
\hline $7-9$ & 14.9 & 25.2 \\
\hline $10+$ & 2.7 & 7.9 \\
\hline Total & 100.0 & 100.0 \\
\hline $\mathrm{N}$ & 148 & 151 \\
\hline
\end{tabular}

Source Fieldwork
This is expected because compared to the migrants a higher proportion of indigenes (see Table 1) have had higher education which is a pre-requisite for employment in the formal sector.

Ownership of assets and consumer durable goods by migration status

Ownership of assets and consumer durable goods and physical quality of housing have been used in many studies to assess socio-economic status of households (Ghana Statistical Service 2000, 2007; Mberu 2005; Codjoe 2006; Doocy and Burnham 2006; Collinson et al. 2009; Pinnawala 2009). But access to assets including housing could be influenced by various forms of capitals, institutional structures and processes and the vulnerability context within which people operate. The type, quality and quantity of assets and consumer durable goods that one acquires would also depend on one's taste and preferences. In the study, 15 different assets and consumer durable goods mostly used by the Ghana Statistical Service (2000, 2004, 2007) in the assessment of household wealth were listed and respondents were asked to tick those items that were available, functional and accessible to them in their households. The rationale was to find out the proportion of migrants and indigenes who own these items, and also to compare the results with the national averages on ownership of assets and consumer durable goods. It was also to test the hypothesis of no significant difference between migrants and indigenes in the ownership of assets and consumer durable goods. The items were radio, video, telephone, camera, television, electric fan, electric iron, electric/ Gas stove, refrigerator, bed and mattress, living room furniture, Motor cycle/Motor bike, sewing machine, bicycle and vehicle (Table 3). The results show that seven (Television, refrigerator, telephone, bicycle, motor cycle/motor bike, electric iron/box iron and electric fan) out of the 15 items showed significant difference (at 0.05 significant level) between migrants and indigenes, implying that for most of the items (eight), there were no differences between the two groups. This is expected since these assets and consumer durable goods are basic necessities of urban life and therefore they could be available in households of both migrants and indigenes. Compared with the national averages on ownership of the 15 items, it appears that a higher proportion of migrants and 
indigenes owned these items than the average Ghanaian. This might be due to the fact that Obuasi is a mining town which is associated with higher incomes than the average monthly income in the country.

Quality of housing and facilities by migration status

It has been noted that at the initial stage of migration, migrants of low socio-economic status to urban areas are likely to live with friends or close relations or they may live in squatter settlements because they cannot afford the cost of renting accommodation on their own (Goldscheider 1992). This helps them to adjust to city life and be able to, in the course of time, accumulate capital that could be used to rent their own accommodation (Akand 2005; Jingming and Lulu 2005) or save to convert their initial shacks and huts into durable and respectable housing (Shinya 2004). This implies that at destination, the quality of house that a

Table 2 Main occupation by education and migration status

\begin{tabular}{|c|c|c|c|c|c|c|c|c|}
\hline \multirow[t]{2}{*}{ Main occupation } & \multicolumn{4}{|c|}{ Migrants } & \multicolumn{4}{|c|}{ Indigenes } \\
\hline & None & Primary & Middle/JHS & Higher & None & Primary & Middle/JHS & Higher \\
\hline Farming & 8.3 & 3.8 & 0.0 & 0.0 & 0.0 & 0.0 & 5.0 & 1.0 \\
\hline Civil service & 6.3 & 7.7 & 0.0 & 18.9 & 0.0 & 0.0 & 12.5 & 66.7 \\
\hline Trading & 25.0 & 23.1 & 20.8 & 13.2 & 100.0 & 100.0 & 40.0 & 8.6 \\
\hline Mining & 50.0 & 50.0 & 75.0 & 60.4 & 0.0 & 0.0 & 27.5 & 14.3 \\
\hline Pensioner & 2.1 & 11.1 & 4.2 & 0.0 & 0.0 & 0.0 & 7.5 & 9.5 \\
\hline Daily labourer & 6.3 & 0.0 & 0.0 & 0.0 & 0.0 & 0.0 & 0.0 & 0.0 \\
\hline Other & 2.1 & 3.8 & 0.0 & 7.5 & 0.0 & 0.0 & 7.5 & 0.0 \\
\hline Total & 100.0 & 100.0 & 100.0 & 100.0 & 100.0 & 100.0 & 100.0 & 100.0 \\
\hline $\mathrm{N}$ & 48 & 26 & 24 & 53 & 1 & 2 & 40 & 105 \\
\hline
\end{tabular}

Source Fieldwork

Table 3 Ownership of assets and consumer durable goods by migration status

\begin{tabular}{|c|c|c|c|c|c|c|c|}
\hline \multirow[t]{2}{*}{ Item } & \multicolumn{2}{|c|}{ Migrants } & \multicolumn{2}{|c|}{ Indigenes } & \multirow{2}{*}{$\begin{array}{l}\text { National } \\
\text { averages (\%) }\end{array}$} & \multirow[t]{2}{*}{$\chi^{2}$} & \multirow[t]{2}{*}{$P<0.05$} \\
\hline & No. & $(\%)$ & No. & $(\%)$ & & & \\
\hline Radio & 140 & 93.0 & 145 & 97.0 & 69.4 & 2.25 & .133 \\
\hline Television & 121 & 80.0 & 135 & 91.0 & 27.1 & 7.46 & $.006^{*}$ \\
\hline Video & 103 & 68.0 & 97 & 66.0 & 10.3 & .241 & .624 \\
\hline Electric/gas stove & 75 & 50.0 & 68 & 46.0 & 11.2 & .415 & .519 \\
\hline Refrigerator & 98 & 65.0 & 115 & 78.0 & 21.3 & 5.97 & $.014^{*}$ \\
\hline Camera & 14 & 9.0 & 14 & 10.0 & 2.5 & .001 & .970 \\
\hline Telephone & 115 & 76.0 & 126 & 85.0 & 2.8 & 3.85 & $.050 *$ \\
\hline Bed with mattress & 136 & 90.0 & 139 & 94.0 & 88.2 & 1.50 & .220 \\
\hline Living room furniture & 134 & 89.0 & 139 & 94.0 & 63.5 & 2.52 & .112 \\
\hline Bicycle & 39 & 26.0 & 8 & 5.0 & 20.6 & 23.53 & $.001 *$ \\
\hline Motor cycle/motor bike & 24 & 16.0 & 4 & 2.7 & 2.0 & 15.32 & $.001 *$ \\
\hline Vehicle & 19 & 13.0 & 15 & 10.0 & 4.3 & .444 & .505 \\
\hline Sewing machine & 67 & 44.0 & 75 & 51.0 & 21.4 & 1.19 & .275 \\
\hline Electric fan & 115 & 76.2 & 128 & 87.0 & 27.9 & 5.23 & $.022 *$ \\
\hline Electric iron/box iron & 120 & 80.0 & 145 & 98.0 & 25.2 & 25.39 & $.001 *$ \\
\hline
\end{tabular}

Source Fieldwork and Ghana Statistical Service (2005). * Significant at 0.05 
migrant resides in could be a measure of his/her livelihood status. In most studies, housing quality is used as a measure of socio-economic status and is often assessed based on type of dwelling, ownership status and physical characteristics such as materials used for the floor, walls and roof, main sources of drinking water, light and energy, toilet facilities and the number of rooms available for sleeping in a house (Ghana Statistical Service 2002; UNDP 2007; Mberu 2005; Pinnawala 2009).

The results show that besides four items or facilities (Material for wall, energy for lighting, waste disposal and main source of drinking water) where the proportions were higher for indigenes than migrants, equal proportions of migrants and indigenes live in houses with similar facilities. This assertion is also confirmed by the results from a Chi square statistic test at 95 per cent confidence level which generally showed no significant differences in the quality of housing and facilities between migrants and indigenes in seven out of the 11 items (Table 4).

Comparing access to quality housing and facilities between migrants and indigenes on the one hand and the average person (national average) on the other, it can be concluded that higher proportions of migrants and indigenes in the Obuasi Municipality have access to quality housing and facilities than the average person in Ghana. This is expected because the Obuasi Municipality is endowed with natural (minerals, land, forest, etc.), financial (higher incomes) and physical (physical infrastructure) capitals or resources which enable the people to have access to quality housing and facilities.

Subjective assessment of livelihood status of both migrants and indigenes

Self assessment of livelihood status is one of the methods for determining household livelihood status (Geest 2005). Individuals can best describe their incomes and the quantity and quality of consumer durable goods they possess more than anyone else. However, the limitation associated with this method is that it is subjective and not based on any clearly defined benchmark and therefore cannot ensure objective assessment of livelihood status across households. Nonetheless, it provides a clue about how people perceive their livelihood status: whether it has improved or remained unchanged or deteriorated. From both the in-depth interviews and focus group discussions, both migrants and indigenes were asked how they perceived their livelihood status. The excerpts below are some of the most common views expressed by the respondents. In an in-depth interview, a male respondent reported that while the livelihood status of some indigenes were higher or better than his, he felt that his livelihood status was also better than others (some indigenes): Some indigenes are better than me but $l$ am also better than others. For example, some of my friends who also

Table 4 Quality of housing and facilities by migration status

\begin{tabular}{|c|c|c|c|c|c|c|c|}
\hline \multirow[t]{2}{*}{ Facility } & \multicolumn{2}{|c|}{ Migrants } & \multicolumn{2}{|c|}{ Indigenes } & \multirow{2}{*}{$\begin{array}{l}\text { National } \\
\text { average } \\
(\%)\end{array}$} & \multirow[t]{2}{*}{$\chi^{2}$} & \multirow[t]{2}{*}{$P<0.05$} \\
\hline & No. & $(\%)$ & No. & $(\%)$ & & & \\
\hline Dwelling (compound house) & 88 & 58.0 & 85 & 57.0 & 60.3 & 5.04 & .411 \\
\hline Main materials of wall (cement) & 127 & 84.1 & 133 & 90.0 & 44.1 & 4.27 & .371 \\
\hline Main materials of floor (cement) & 145 & 96.0 & 145 & 98.0 & 84.9 & 4.17 & .383 \\
\hline Material of roof (corrugated iron sheets) & 147 & 97.0 & 146 & 97.0 & 65.7 & 5.97 & .309 \\
\hline Occupancy status (rented) & 84 & 56.0 & 83 & 56.0 & 41.1 & 11.45 & $.022 *$ \\
\hline Energy for lighting (electricity) & 134 & 89.0 & 142 & 96.0 & 48.9 & 5.46 & $.019 *$ \\
\hline Energy for cooking (charcoal) & 121 & 80.1 & 81 & 55.0 & 32.0 & 29.80 & $.001 *$ \\
\hline Toilet facility mostly used (KVIP) & 82 & 54.0 & 79 & 53.0 & 31.3 & 3.24 & .356 \\
\hline Public dump for disposal of waste & 127 & 84.1 & 138 & 93.2 & 59.9 & 8.02 & $.046^{*}$ \\
\hline Main source of drinking water (pipe-borne water) & 100 & 68.0 & 116 & 78.4 & 41.6 & 6.37 & .095 \\
\hline Total number of rooms available for sleeping (two) & 64 & 42.4 & 64 & 43.2 & 75.6 & 4.14 & .844 \\
\hline
\end{tabular}

Source Fieldwork and Ghana Statistical Service (2000). * Significant at 0.05 
retired from the mines like myself have dissipated their pension money. Some have not been able to build houses in their own hometown even though some have access to free land but I have built a house. Some of them are renting houses in their own hometown which is an indication that I am better than some (A male opinion leader aged about 60 years).

In a focus group discussion, one female respondent said her livelihood status had improved: Life has improved, we have been able to put up our own house and the children have completed school and are now working so 1 can see that life has improved. We are also able to send some foodstuffs, money and second hand clothing to our close relations at home occasionally. So, my life has improved better than some of them while others too enjoy better life than me (A female participant aged about 45 years).

Furthermore, a male artisan and an opinion leader reported that: Yes, life has improved better than when $l$ was in the north; my children have had good education and are doing big jobs. I have three wives, l have built a house for each one of them and also built one for myself. Also, l remit items such as maize, money and second hand clothing to my brothers at home. So, I can say that my economic situation has improved and we are moving forward (A male artisan and an opinion leader aged about 55 years).

But some migrants, especially those engaged in farming indicated that their livelihood status has not improved. For example, a male respondent said this about his livelihood status: I can say that those who hail from Obuasi are better off than myself. The reason being that they own the land and some of them do not pay rent to any landlord but l always hire land for farming every 2 years (A male farmer aged about 45 years).

On the other hand, some indigenes indicated that their livelihood status were better than the migrants while others admitted that that of some migrants were better than them (indigenes). One example of each case is given in the following excerpts: I work in the mines, and l have been able to build two houses and also have two commercial vehicles because my income is higher than some of the people from the north (migrants). Also, this is my hometown, $l$ have free access to the family farmland if $l$ want to engage in farming (A male employee in the mines aged about 45 years).

I am trader, this is my hometown, 1 have lived here with some of the northerners (migrants) since birth. They are very hardworking people; some have built houses here and also in their hometown. In fact, some are better off economically than me (A female trader aged about 50 years).

Assessment of household income

Although income as an indicator for measuring socioeconomic status is associated with some inaccuracies such as reporting biases, seasonal nature of incomes in agricultural economies and rapid inflation it is often used to assess socio-economic or wealth status (Ghana Statistical Service 2000, 2007; Doocy and Burnham 2006; Madise et al. 2007; Vyas and Kumaranayake 2008). The total sample size of 299 (both migrants and indigenes) was ranked into five quintiles on the basis of total monthly household income as reported by the respondents (Gwatkin et al. 2000).

The results in Table 5 show that about three out of 10 migrants compared with two out of 10 indigenes were within the lowest quintile of less than $\mathrm{GH} \phi 100.00$ (US\$50.00) (Exchange rate was $\mathrm{GH} \phi$ 2.00-US\$ 1.00 in 2010) per month. But a little more than a quarter of the indigenes compared to a quarter of migrants earned GH $\phi 300.00$ (US\$150.00) or more per month (i.e. the fourth and highest quintiles). The national averages, on the other hand, showed higher proportions of both migrants and indigenes in the lowest and second quintiles while both groups (migrants and indigenes) have lower proportions from the third to the highest quintiles compared to the national average. The data suggest that on the average more indigenes than migrants earned higher income per month, implying that the income levels of the indigenes was relatively higher than that of the migrants. However, it must be noted that either of the two groups (migrants and indigenes) could under estimate or over estimate their monthly income for reasons best known to them.

\section{Discussion}

The paper examined livelihood status of migrants from the northern savannah zone who were permanent residents in the Obuasi Municipality. The results showed that the migrants were generally younger than 
Table 5 Household income per month by quintile and migration status

\begin{tabular}{lllll}
\hline $\begin{array}{l}\text { Quintile } \\
\text { group }\end{array}$ & $\begin{array}{l}\text { Monthly } \\
\text { income }(\mathrm{GH} \phi)\end{array}$ & $\begin{array}{l}\text { Category of } \\
\text { respondents }\end{array}$ & $\begin{array}{l}\text { National } \\
\text { average }\end{array}$ \\
\cline { 3 - 4 } & & Migrants & Indigenes & \\
\hline Lowest & Less than 100 & 29.1 & 24.5 & 12.6 \\
Second & $100-199$ & 28.5 & 33.0 & 15.5 \\
Third & $200-299$ & 17.1 & 15.7 & 18.2 \\
Fourth & $300-399$ & 12.0 & 13.5 & 21.6 \\
Highest & $400+$ & 13.2 & 13.3 & 32.0 \\
Total & & 100.0 & 100.0 & 100.0 \\
\hline
\end{tabular}

Source Fieldwork and GLSS (Round 5), 2008

Exchange rate: $\mathrm{GH} \not 2.00$ to US\$ 1.00 in 2010

the indigenes, which is consistent with other studies that migrants are mostly younger than indigenes (De Haan et al. 2000; Waddington and Sabates-Wheeler 2003; Mberu 2005; Tanle 2010). The younger age of the migrants means they are more capable of improving upon their human capital (Knowledge and skills) and ultimately their livelihood status. There is higher illiteracy among migrants (32.0 per cent), which is even higher than the national average of 28.5 per cent, than indigenes ( 0.7 per cent). This finding corroborates that of Mberu (2005) and Tanle (2010) that most migrants compared to the indigenes are illiterates. This could be attributed to the fact that formal education in Northern Ghana started a century after that of the southern sector (Bening 1971; Der 1994; Songsore 2003). As indicated in the conceptual framework, human capital (knowledge and skills) is an important factor that determines the livelihood activity that one engages in and hence one's livelihood status. Additionally, it has been noted that formal education leads to better opportunities in life which could enhance one's livelihood status (Waddington and Sabates-Wheeler 2003). The results generally indicated that those with some formal education (Middle/JHS or higher) were mostly employed in the formal sector while those with primary school education or no formal education were mostly engaged in the informal sector (trading). In general, the quality of human capital of a migrant or an indigene would, to a greater extent, influence his/her livelihood status.

Mining and civil service were the main livelihood activities of male migrants and male indigenes respectively while trading was the main livelihood activity for females in both categories, particularly female migrants due to low level of education. This explains why none of the female migrants compared to about 40 per cent of their indigene counterparts was employed in the civil service. The fact that mining is the main livelihood activity of male migrants confirmed the culture of labour migration from the three northern regions to the mining centres, initiated by the colonial government and continued even after independence (Songsore 2003; Abane 2008; Tanle 2010). Also, given the low level of formal education among the male migrants, they are likely to engage in jobs at the lower ranks (Security, sanitary, constructional and messenger work) in the mining sector (Tanle 2010). This observation ties in with findings from other studies that most migrants are concentrated at the lowest levels of the occupational scale due to their deficient education and skills levels (Kwankye et al. 2007; Pinnawala 2009; Tanle 2010).

The results on ownership of assets and consumer durable goods showed no significant difference between migrants and indigenes. This was expected because both migrants and indigenes resided in urban areas where consumer durable goods such as radio, television and refrigerator are basic household items which form part of the urban culture. Moreover, unlike some rural areas, most urban areas have the basic physical capital such as electricity, roads and potable water which provide the foundation for the use of such consumer durable goods. This is consistent with Mberu's (2005) findings in Ethiopia which concluded that there was no statistically significant difference between permanent migrants and non-migrants in terms of ownership of assets and consumer durable goods. It was also found out that equal proportions of migrants and indigenes lived in houses with similar facilities or characteristics. This was also confirmed by the results of the Chi square statistic. Since the migrants were permanent migrants, they could afford to live in quality houses because they might have saved part of their income over the years for better accommodation. For instance, it has been noted that in most cases permanent migrants are keen to secure better houses whilst temporary migrants are content with living in huts and shacks but eager to build better houses in their home towns (Mabele 2007; Konseiga et al. 2009). Also, it could be due to the fact that in a well planned urban settlement like the Obuasi Municipality the characteristics of houses are not likely to 
differ much compared to that between urban and rural settlements.

From the qualitative data, some of the migrants felt that their livelihood status had improved at their destination. The indicators of improved livelihood status in their own estimation were ability to build a house at destination or at one's hometown, educate one's children (Formal education) and send remittances to close relations at home to ensure food security. In particular, ownership of a house was the basis of comparison of their livelihood status with the indigenes. This is expected because ownership of landed property such as a house has been used in some studies as a measure of improvement in the livelihood status of migrants (Mberu 2005; Pinnawala 2009). However, the overall perception is that while some indigenes claimed that their livelihood status were better than the migrants, some migrants felt that their livelihoods status were even better than some of the indigenes.

The results from the income quintiles suggest that more indigenes than migrants were within the fourth and highest income quintiles suggesting that indigenes generally earned fairly higher income than the migrants. This implies that in terms of income, the livelihood status of the indigenes was relatively higher than that of the migrants. This is expected because the indigenes compared to the migrants are more likely to have greater access to natural capital such as land, financial capital such as loans from financial institutions because they may have better collateral security and more effective social capital than migrants. These capitals could yield some income directly or indirectly for indigenes than migrants.

\section{Conclusion}

Although the study failed to control for migrants' age at the time of their arrival and duration of stay at destination vis-a-vis that of the indigenes, the findings showed no significant difference between migrants and indigenes in ownership of basic household durable goods and quality of housing. However, the indigenes earned relatively higher than the migrants. This can be attributed to the fact that the institutional structures and processes that influence access to productive resources are more likely to favour indigenes than migrants. This means that migrants may be endowed with some human capital but the ability to utilize it optimally in any activity would depend on institutional policies such as entry requirements in the formal or informal sector employment or willingness to abide by certain contractual agreement as a precondition to have access to land or to be included in any business activity or the general power dimension at destination. But to the migrants, their livelihood status had improved since they were able to build houses, educate their children and even remit their relations at home occasionally. Improvement in the livelihood status of migrants at destination could induce further north-south migration in Ghana. There is therefore the urgent need for conscious efforts by government and other stakeholders to bridge the gap of unequal socioeconomic and infrastructural development between the northern and southern parts of the country. This paper contributes to the growing discourse on migration and livelihood, and concludes that improvement or otherwise in the livelihood status of a migrant at a destination is context dependent.

Open Access This article is distributed under the terms of the Creative Commons Attribution License which permits any use, distribution, and reproduction in any medium, provided the original author(s) and the source are credited.

\section{References}

Abane, A. M. (2008). Poverty and inequality in Ghana: Focus on the Northern regions. In S. B. Kendie \& P. Martens (Eds.), Governance and sustainable development (pp. 160-178). Cape Coast: Marcel Hughes Publicity Group.

Akand, M. K. (2005). Folk culture and Urban adaptation: A case study of the Paharia in Rajshahi. Asian Folklore Studies, 64, 15-45. Retrieved 27 June 2009 from http://www. questia.com/PM.qst?a=o\&se $=$ gglsc $\& d=5010862809$.

Alam, N., \& Streatfield, P. K. (2009). Parents' migration and children's education in Matlab, Bangladesh. In M. Collinson, K. Adazu, M. White, \& S. Findley (Eds.), The dynamics of migration, health and livelihoods: INDEPTH network perspectives (pp. 109-119). England: Ashgate Publishing Ltd.

Anarfi, J. K., Awusabo-Asare, K., \& Nsowah-Nuamah, N. N. N. (1999). Push and pull factors of international migration: Country report. European Commission: Ghana and Brussels.

Anarfi, J., Kwankye, S., Ababio, O., \& Tiemoko, R. (2003). Migration from and to Ghana: A background paper. Development Research Centre on Migration, Globalization and Poverty, working paper C4, 1-38, Retrieved 8 Feb 2009 http://www.migrationdrc.org.

Bening, R. B. (1971). The development of education in Northern Ghana 1908-1957. Ghana Social Science Journal, 1(2), 21-41. 
Cahn, M. (2002). Sustainable livelihoods approach: Concept and practice. Retrieved 4 Nov 2003 www.devnet.org.nz/ conf/2002/papers/Cahn_Mirandapdf.

Camdessus, M. (1990). Aiming for high quality growth: Financial and development. Washington DC: International Financial Corporation.

Carney, D. (1998). Implementing the sustainable rural livelihoods approach. In D. Carney (Ed.), Sustainable rural livelihoods: What contribution can we make?. London: Department of International Development (DFID).

Chambers, R., \& Conway, G., (1992). Sustainable rural livelihoods: Practical concepts for the 21st century. Brighton: Institute of Development Studies, (discussion paper 29).

Codjoe, S. A. N. (2006). Migrant versus indigenous farmers: An analysis of factors affecting agricultural land use in the transitional agro-ecological zone of Ghana. Danish Journal of Geography, Geografisk Tidsskrif, 106(1), 103-113.

Collinson, A. M., Gerritsen, A. A. M., Clark, S. J., Kahn, K., \& Tollman, M. S. (2009). Migration and socio-economic change in rural South Africa, 2000-2007. In M. Collinson, K. Adazu, M. White, \& S. Findley (Eds.), The dynamics of migration, health and livelihoods: INDEPTH network perspectives (pp. 81-108). England: Ashgate Publishing Ltd.

De Haan, A., Brock, K., Carswell, G., Coulibaly, N., Seba, H., \& Toulifique, A. K. (2000). Migration and livelihoods: Case studies in Bangladesh, Ethiopia and Mali. Brighton: Institute of Development Studies (IDS), University of Sussex, research report 46, 1-35. Retrieved 10 Oct 2008 www.ntd.co.uk/idsbookshop/details.asp? $=579$.

Der, B. G. (1994). The development of education in Northern Ghana during the Colonial Era. Journal of the Institute of Education, 3(1), 100-116.

Dickson, K. B., \& Benneh, G. (1988). A new geography of Ghana. UK: Longman Group Limited.

Doocy, S., \& Burnham, G. (2006). Assessment of socio-economic status in the context of food insecurity: Implications for field research. World Health and Population. 1-10, Retrieved 11 April 2009 http://www.jhsph.edu/refugee/ publications_tools/publications/_pdf/foodinsecurity.pdf.

Ellis, F. (2000). Rural livelihoods and diversity in developing countries. New York: Oxford University Press Inc.

Ellis, F. (2003). A livelihoods approach to migration and poverty reduction. pp. 1-21, Retrieved 3 Oct 2006. http://www. livelihoods.org/emailupdate/march2004/emailupdate. html-42k.

Farrington, J., Ramasut, T., \& Walker, J. (2002). Sustainable livelihoods approaches in urban areas: General lessons, with illustrations from Indian cases. Overseas Development Institute, working paper 162, pp. 1-53. Retrieved Jan 2008 http://www.Odi_org.uk/publications/working_papers/ wp162.pdf.

Friedman, J. (1992). Empowermwnt: The politics of alternative development. Cambridge: Blackwell publishers.

Geest, V. D. K (2005). Local perceptions of migration and livelihood in Northwest Ghana: The home community perspective. Retrieved 13 Oct 2006 http://www.iss.ni/ ceres/vdgeest.pdf.

Ghana Statistical Service. (2000). Ghana living standards survey: Report of the fourth round (GLSS4). Accra: Ghana Statistical Service.
Ghana Statistical Service. (2002). 2000 Population and housing census. Accra: Ghana Statistical Service.

Ghana Statistical Service (2005). Ghana population data analysis report: Socio-economic demographic trends, (Vol. 1), Accra: Ghana Statistical Service

Ghana Statistical Service. (2007). Pattern and treads of poverty in Ghana 1991-2006. Accra: Ghana Statistical Service.

Ghana Statistical Service. (2008). Ghana living standards survey: Report of the fifth round (GLSS 5). Accra: Ghana Statistical Service.

Ghana Statistical Service. (2012). 2010 population and housing census: Summary report of final results. Accra: Ghana Statistical Service.

Ghana Statistical Service (GSS), Noguchi Memorial Institute for Medical Research (NMIMR), and ORC Macro. (2004). Ghana demographic and health survey 2003. Calverton Maryland: GSS, NMIMR, and ORC Macro.

Goldscheider, C. (1992). Urban migrants in developing nations: Pattern and problems of adjustment. In C. Goldscheider (Ed.), Fertility transitions (pp. 1-16). Family Structure and Population Policy, Colorado: Westview Press.

Gwatkin, D. R., Rustein, S., \& Johnson, K. (2000). Socio-economic differences in Brazil. Washington D. C.: HNP/Poverty Thematic Group of the World Bank, Retrieved 12 July 2008 http://www.worldbank.org/poverty/health/index.htm.

Heering, L., Van der Erf, R., \& Wissen, L. V. (2004). The role of family networks and migration culture in the continuation of Moroccan emigration: A gender perspective. Journal of Ethnic and Migration Studies, 30(2), 323-337.

Jingming, L., \& Lulu, L. (2005). Becoming Stratified: Residential spaces, lifestyles, social networks and class identity: An empirical study of social stratums in urban China. Sociological Research, 3, 52-81.

Konseiga, A., Zulu, E. M., Bocquier, P., Muindi, K., Beguy, D., \& Ye, Y. (2009). Assessing the effect of mother's migration on childhood mortality in the informal settlements of Nairobi. In M. Collinson, K. Adazu, M. White, \& S. Findley (Eds.), The dynamics of migration, health and livelihoods: INDEPTH network perspectives (pp. 123-138). England: Ashgate Publishing Ltd.

Kothari, U. (2002). Migration and chronic poverty. Chronic Poverty Research Centre. 1-32, Retrieved 16 Aug 2007 http://www.chronicpoverty.org/pdfs/16/kothari.

Kwankye, S. O., Anarfi, J. K., Tagoe, A. C., \& Castaldo, A. (2007). Coping strategies of independent Child migrants from Northern Ghana to Southern Cities. Development Research Centre on Migration, Globalization and Poverty, working paper T-23, Retrieved 21 Aug 2009 http://www. migrationdrc.org.

Mabele, A. L. (2007). Enhancing informal economy in subSaharan African cities: A case study of Kinshasa. A Master of Science dissertation submitted to the Faculty of Engineering and the Built Environment, Johannesburg: University of the Witwatersrand.

Madise, N., Zulu, E., \& Ciera, J. (2007). Is poverty a driver for risky sexual behaviour? Evidence from National Surveys of Adolescents in four African countries. In Okonofua, F. E. (ed.). African Journal of Reproductive Health 11(3), 83-98. 
Mberu, U. B. (2005). Internal migration and household living conditions in Ethiopia. Nairobi: African Population and Health Research Center, working paper No. 31.

Meikle, S., Ramasut, T., \& Walker, J. (2001). Sustainable urban livelihoods: Concepts and implications for policy. Working paper 112, Retrieved Dec 2006 http://uc/.ac.uk/dpu/ publications/working/\%20papers\%20pdf/wp112pdf.

Moser, C. (1998). The asset vulnerability framework: Reassessing urban poverty reduction strategies. World Development, 26(1), 15-25.

Nabila, J. S. (1974). Theoretical and conceptual foundations of the migration process in Africa. Unpublished Ph.D. Thesis. Michigan: Michigan State University.

Nabila, J. S. (1985). Internal migration and regional development in Ghana. In Regional Institute of Population Studies (RIPS) (ed.). Internal Migration and Regional Development in Africa, Accra: Ghana Universities Press. pp. 205-223.

Narayan, D., Chambers, R., Shah, M. K., \& Petesch, P. (2000). Voices of the poor: Crying out for change. New York: Oxford University Press.

Overseas Development Administration (ODA). (1995). Pregress report on ODA policy objectives: 1992/3 and 1993/4. London: Overseas Development Administration.

Pinnawala, M. (2009). Gender Transformation and female migration: Sri Lankan domestic workers negotiate transnational household relations. A Ph.D. thesis submitted to the Institute of Social Studies, The Hague.

Scoones, 1. (1998). Sustainable rural livelihoods: A framework for analysis. Institute of Development Studies (IDS). Brighton: University of Sussex, working paper no. 72, pp. 1-22. Retrieved 17 Sept 2007 http://www.ids.ac.uk/ids/ bookshop/wp/wp72pdf.

Shinya, M. (2004). Urban housing security for low income person in China. Journal of Housing Welfare, 1, 45-50.

Songsore, J. (2003). Regional development in Ghana: The theory and the reality. Accra: Woeli Publishing Services.
Songsore, J., \& Denkabe, A. (1995). Challenging rural poverty in Northern Ghana: The case of the upper-west region. Trondheim: Reprosentralen.

Tanle, A. (2010). Livelihood status of migrants from the northern savannah zone resident in the Obuasi and Techiman Municipalities. A Ph.D. Thesis submitted to the Department of Population and Health, University of Cape Coast, Cape Coast, Ghana.

Tsegai, D. (2005). The economics of migration in the Volta Basin of Ghana: Household and district-level analysis. A published Ph.D. Thesis, Cuvillier Verlag Gottingen, Germany: University of Bonn.

UNDP. (2007). Ghana human development report 2007: Towards a more inclusive society. Accra: UNDP.

UNDP (2009). Human development report 2009: Overcoming barriers: Human mobility and development. New York: UNDP, Retrieved 18 Dec 2009 http://www.hdr.undp.org.

Vyas, S., \& Kumaranayake, L. (2008). Constructing socioeconomic status indices: How to use principal components analysis. Oxford University Press, Retrieved: 19 Oct 2008 http://www.heapoloxfordjournals.org/cgi/content/full/ 21/6/459.

Waddington, H., \& Sabates-Wheeler, R. (2003). How does poverty affect migration choice: A review of literature. University of Sussex, working paper T3, 1-22, from Retrieved 6 Aug 2008 http://www.migrationdrc.org/public ations/working_papers/WP.T3.

Yaro, J. A. (2006). Is deagrarainisation real? A study of livelihood activities in rural northern Ghana. Journal of Modern Africa Studies, 44(1), 125-156.

Young, H. (2006). Livelihoods, migration and remittance flow in times of crisis and conflicts: Case studies for Durfur, Sudan. Feinstein International Centre, pp. 1-33, Retrieved 11 March 2009 http://www.odi.org.uk/resources/down load/295.pdf. 